Pamiętnik Literacki 2021, 3, s. 211-221

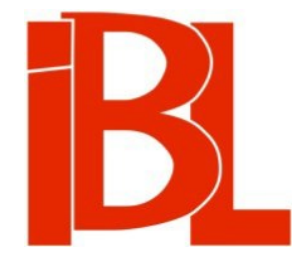

\title{
Norwid w badaniach Michała Głowińskiego - kilka uwag
}

Krzysztof Trybuś 
Pamiętnik Literacki CXII, 2021, z. 3, PL ISSN 0031-0514

DOI: $10.18318 / \mathrm{pl} .2021 .3 .11$

KRZYSZTOF TRYBUŚ Uniwersytet im. Adama Mickiewicza, Poznań

\section{NORWID W BADANIACH MICHAŁA GLOWIŃSKIEGO - KILKA UWAG}

\section{Nienapisana książka}

O tym, że nigdy nie powstała książka Michała Głowińskiego na temat poezji Norwida, mówi sam badacz, uważając to za rodzaj niespełnienia naukowego:

Zamierzałem w swoim czasie napisać cykl studiów lub ciągłą książkę o poetyce Norwida. Napisałem kilka artykułów, w wyborze moich prac, [...] w piątym tomie, jest sześć artykułów o nim. To są artykuły dość długie i, jak myślę, dość zasadnicze. Norwid ma całą ekipę oddanych badaczy, można powiedzieć fanów, wielbicieli, miłośników; prac o nim powstaje dużo. Przestałem się tym zajmować, nie śledzę tego, nie wiem zatem, czy moje artykuły funkcjonują. Interesowała mnie poetyka Norwida i jej swoistości. Otóż wydaje mi się, że będąc poeta fantastycznie nowatorskim, odwoływał się do tradycyjnych, od epoki romantyzmu traktowanych jako archaiczne, wzorców literackich. To jedna z jego osobliwości, że posługiwał się przypowieściami, co wiązało się $z$ tak ważnym dla niego światopoglądem religijnym. Posługiwał się alegoriami, mimo że od czasu, w którym Goethe przeciwstawił symbol alegorii, aprobując pierwszy, odrzucając drugą, minął wiek. Norwid był poetą alegorii. Zajmowałem się też problemami szczegółowymi, mianowicie rolą zwrotów do drugiej osoby i pewnego rodzaju refleksją metajęzykową, ważną u Norwida, która się wyraziła w słynnej formule „odpowiednie dać rzeczy słowo”. Zająłem się także jednym wierszem osobno, mianowicie wierszem Powieść, niezwykle ciekawym między innymi dlatego, że powieść była podstawowym gatunkiem literackim XIX wieku. Dla Norwida jest ona forma absolutnie nie do przyjęcia. Inna sprawa, że polska powieść pierwszej połowy XIX wieku nie jest zjawiskiem najwyższych lotów, ale przecież on czytał również po francusku, znał powieści niemieckie, angielskie. Jednakże powieść jest dla niego gatunkiem niemetafizycznym, błahym. To pokazuje, że w tym przypadku kategoria gatunku literackiego, czyli w zasadzie ściśle formalna, była czymś w rodzaju kategorii estetycznej. Powieść mogła sobie pozwolić tylko na opowiadanie błahych fabuł o codzienności, natomiast, że tak powiem, nie wstępowała na wyżyny ludzkiego ducha. Rzecz inna, że Norwid odwoływał się między innym do bardzo konkretnej powieści. Mianowicie do głośnego w swoim czasie, dzisiaj trudno czytelnego dzieła Józefa Korzeniowskiego Krewni, które zyskało wielki rozgłos, co nie znaczy, że było chwalone. Jak powiadam, nie udało mi się napisać dużego cyklu na temat poezji Norwida, nie udało mi się napisać książki ciągłej i właściwie traktuję to jako niespełnienie ${ }^{1}$.

Ten swobodny tok opowieści Głowińskiego oddaje jego ogólny pogląd na istotę poezji Norwida, nie odsłania jednak wszystkich aspektów z jego poezją związanych, które poruszył i omówił autor sześciu artykułów z tomu 5 Prac wybranych ${ }^{2}$. Co więcej - przytoczone tu słowa zdaja się umniejszać znaczenie owych artykułów,

1 M. Głowiński, G. W ołowi e c, Czas nieprzewidziany. Długa rozprawa bez pana, wójta i plebana. Warszawa 2018, s. 296-298.

2 M. Gło w i ń s k i, Intertekstualność, groteska, parabola. Szkice ogólne i interpretacje. Kraków 2000 (Prace wybrane. Red. R. Ny cz. T. 5): Norwida wiersze-przypowieści, Ciemne alegorie Norwida, Gorzkie kalambury. O „Purytanizmie” Cypriana Norwida, Wokół „Powieści” Norwida, Norwidowska druga osoba, Odpowiednie dać rzeczy słowo. 
skoro nie złożyły się one na monograficzną całość, jak stało się to w przypadku studiów nad Tuwimem i Leśmianem.

W badaniach nad spuścizną Norwida bywało, że pojedyncze wypowiedzi i rozproszone głosy miały nieraz większą wagę niż rozległe studia, by przypomnieć dwa artykuły Zofii Stefanowskiej: Norwid - pisarz wieku kupieckiego i przemysłowego oraz Norwidowski romantyzm ${ }^{3}$. Opublikowane w 1968 roku, na lata wyznaczyły kierunek refleksji o poezji autora Vade-mecum, zanim (po upływie ćwierćwiecza) weszły do (niewielkich rozmiarów) książki Stefanowskiej poświęconej Norwidowi ${ }^{4}$, już jako klasyczne rozprawy. Warto też pamięcią wrócić do ogłoszonego przed laty szkicu Jana Błońskiego Norwid wśród prawnuków ${ }^{5}$, który stał się podstawowym tekstem wtajemniczającym w twórczość poety wiele pokoleń studentów polonistyki, aż do dzisiaj. Można też w dawniejszym okresie, w czasach pierwszych rozpoznań estetyki twórcy Quidama, odnaleźć siłę i znaczenie pojedynczego głosu - wskażę tu przede wszystkim na studium Stefana Kołaczkowskiego Ironia Norwida, opublikowane w „Drodze” (1933, nr 11), w 50 rocznicę śmierci poety; przytaczane niejednokrotnie przez norwidologów, czeka wciąż na kontynuację i rozwinięcie w monograficznym ujęciu problematyki ironii w jego twórczości.

Spośród tych sześciu artykułów, o których wspomina Głowiński, większość ukazała się na początku lat siedemdziesiątych ubiegłego wieku, data ich powstania łączy się mniej lub bardziej ściśle z 150 rocznica urodzin Norwida. Najbardziej znane studium, Norwida wiersze-przypowieści, miało pierwotnie formę referatu, wygłoszonego na sesji jubileuszowej, która odbyła się 23-25 IX 19716. W tym też roku wyszły drukiem artykuły Wokót „Powieści” Norwida („Pamiętnik Literacki” 1971, z. 3) oraz Odpowiednie dać rzeczy słowo - komentarze do aforyzmów (,,Tygodnik Powszechny" 1971, nr 44). Zaledwie rok później ukazał się tekst Norwidowska druga osoba, opublikowany w „Rocznikach Humanistycznych” (t. 19 〈1972〉, z. 2: O sztuce literackiej. Prace ofiarowane Czesławowi Zgorzelskiemu). Artykuły te były niewątpliwie istotną częścią dorobku naukowego ich autora, kształtującego w tym okresie własny typ postawy badawczej, związanej metodologicznie ze strukturalno-komunikacyjnym rozumieniem literatury. W cytowanej tu na wstępie wypowiedzi Głowiński nie wskazuje na znaczenie poezji Norwida w innych swoich szkicach naukowych, w których pojedynczo niekiedy przytaczane wiersze tego poety stanowiły swoistego rodzaju interpretacyjne exemplum dla tez formułowanych przez badacza, jak np. Ostatni despotyzm z cyklu Vade-mecum, przywoływany w głośnym niegdyś tekście Wirtualny odbiorca w strukturze utworu poetyckiego, czy Idee i praw$d a-\mathrm{w}$ równie znanym (i ciagle ważnym dla studiów spacjologicznych w literaturze) szkicu Przestrzenne tematy i wariacje ${ }^{7}$.

Z. St efa n ow s ka: Norwid - pisarz wieku kupieckiego i przemysłowego. W zb.: Literatura, komparatystyka, folklor. Księga poświęcona Julianowi Krzyżanowskiemu. Red. M. B o k s z c z a n i n, S. Frybes, E. Jankows ki. Warszawa 1968; Norwidowski romantyzm. „Pamiętnik Literacki” 1968, z. 4.

4 Z. St e fa n ow s ka, Strona romantyków. Studia o Norwidzie. Lublin 1993.

5 J. Błoń s ki, Norwid wśród prawnuków. „Twórczość” 1967, nr 5.

6 M. Głowińs ki, Norwida wiersze-przypowieści. W zb.: Cyprian Norwid. W 15-lecie urodzin. Materiały konferencji naukowej. 23-24 września 1971. Red. M. Ż mi g ro d z ka. Warszawa 1973.

7 M. Głow iński: Wirtualny odbiorca $w$ strukturze utworu poetyckiego. W: Style odbioru. Szkice 
Z punktu widzenia rozwoju norwidologii ów poczatek lat siedemdziesiatych był czasem niezwykle ważnym, bo właśnie na lata 1971-1976 przypadło ukazanie się edycji Pism wszystkich Norwida w opracowaniu Juliusza Wiktora Gomulickiego. Recepcja poety nieznanego w XIX wieku, zapóźniona względem rozpoznawania innych wielkich romantyków o 100 przeszło lat, zyskała podstawy i szansę przyspieszenia, a przed badaniami otwierała się możliwość dalszego rozwoju. Stał się on wyraźny w następnej dekadzie, kiedy to zainicjowano ciagła współpracę trzech ośrodków naukowych: skupionego wokół Zofii Trojanowiczowej zespołu przygotowującego kalendarz życia i twórczości Norwida, zespołu sporządzającego pod kierunkiem Jadwigi Puzyniny słownik jezzyka poety oraz grupy badaczy, którym przewodził Stefan Sawicki i których celem było nowe, krytyczne wydanie dzieł wszystkich. Cykl seminariów i konferencji poświęconych Norwidowi, organizowanych przez te środowiska naukowe, a także powołanie czasopisma „Studia Norwidiana” przyczyniły się do rozwoju badań o charakterze systemowym, z możliwością konsekwentnego upowszechniania cząstkowych wyników prowadzonych prac. Tak właśnie powstała owa „ekipa” oddanych Norwidowi badaczy, o której wspomina w cytowanym fragmencie swej wypowiedzi Głowiński - „fanów, wielbicieli, miłośników”.

Należałem do tej generacji norwidologów. Teksty Głowińskiego o poezji Norwida były mi szczególnie bliskie, wprowadzały w tajniki poetyki autora Vade-mecum, a to interesowało mnie najbardziej na początku mojej drogi naukowej. Wydaje mi się, że również wśród moich rówieśników panowało przeświadczenie o aktualności tych studiów. Traktowaliśmy je jako istotne ogniwo badań nad językiem poetyckim Norwida, podobnie ważne były dla nas wspomniane studia Zofii Stefanowskiej dotyczące miejsca tego poety w literaturze polskiej. Wypowiedzi o Norwidzie tych dwojga, uznanych już wtedy, badaczy uważaliśmy za kontynuację dzieła wcześniejszego pokolenia krytyków i historyków literatury odkrywających tajniki poezji autora Quidama, by wymienić tu jedynie Wacława Borowego czy Kazimierza Wykę, których znaliśmy już tylko $z$ ich tekstów krytycznych. Stefanowska i Głowiński odnosili się z życzliwością do ruchu „młodej norwidologii”, uczestnicząc z pewnym dystansem w pracach owych trzech ośrodków. Byli obecni w naszych biografiach naukowych często jako promotorzy i recenzenci pisanych przez nas doktoratów i habilitacji. Podobną rolę pełnił Zdzisław Łapiński, ceniony autor znakomitej monografii poświęconej Norwidowi ${ }^{8}$. Były to zresztą czasy, w których Norwidem zajmowali się nie tylko wielcy badacze literatury, ale także znawcy innych dziedzin, interdyscyplinarność stanowiła istotną cechę prowadzonych wtedy studiów nad twórczościa poety. Na organizowanych konferencjach norwidowskich spotykali się literaturoznawcy i językoznawcy, teatrolodzy, historycy sztuki, religioznawcy i filozofowie.

Sesję Język Cypriana Norwida, zorganizowaną przez Pracownię Słownika Języka Cypriana Norwida w listopadzie 1985 w Warszawie, otwierał rektor Uniwersytetu Warszawskiego, Grzegorz Białkowski, fizyk i zarazem profesor-poeta, cieszący się uznaniem wśród społeczności akademickiej w ponurym czasie stanu wojenne-

o komunikacji literackiej. Kraków 1977; Przestrzenne tematy i wariacje. W: Poetyka i okolice. Warszawa 1992.

$8 \quad$ Z. Łapiński, Norwid. Kraków 1971. 
go w Polsce. Mówił: „Jesteśmy wszyscy przekonani o ważności tych badań, o ogromnym znaczeniu, jakie miała myśl Norwida dla XIX wieku i ma dla naszej współczes-

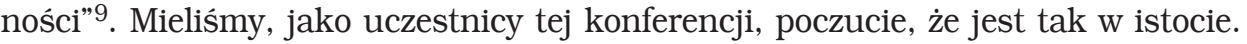
Norwid był dla nas wtedy rzecznikiem prawdy o życiu społecznym, poddawanej stałej presji urzędowego kłamstwa. Jego poezja unicestwiała pychę władzy, jak w znanym wierszu Adama Zagajewskiego Petit: „Te wasze wielkie wydarzenia, / ciosy zadane znienacka / [...] będą / malały, aż osiagna rozmiar / petitu w przypisach do wierszy Norwida"10. Stanisław Barańczak stwierdzał, iż nazwisko Norwida w tym wierszu „pojawia się jako memento, przypominające, że mimo doraźnych triumfów przemocy w ostatecznym rozrachunku liczy się tylko "poezja i dobroć i więcej nic" "11. Sformułował też tezę, że właśnie Norwid jest „ukrytym patronem” twórczości poetów wielu pokoleń rozwijających w swych wierszach nurt „ironicznego moralizmu”, który kontynuację znalazł w „Pokoleniu 68” 12 .

Stało się paradoksalnie - Norwid, który jeszcze w latach sześćdziesiątych XX wieku był kreowany przez peerelowską propagande na prekursora ładu społecznego w czasach komunizmu, przeobraził się ostatecznie w cichego i cierpliwego, ale surowego krytyka owych czasów. O tych zakusach gomułkowskiej propagandy, manipulującej spuścizną romantyków w okresie poprzedzającym wydarzenia marcowe, Głowiński w ten sposób pisał w szkicu Dzieje romantyzmu w PRL. (Najkrótszy kurs), ogłoszonym w 1987 roku poza oficjalnym obiegiem:

Znaleziono wielkiego pisarza, którego romantykom przeciwstawiono - Norwida; na pomysł ten wpadł Zenon Kliszko, który stał się w owych latach partyjnym patronem autora Vade-mecum. A więc Norwid przeciw Mickiewiczowi! Norwid, który miał się przeciwstawiać romantycznemu bezładowi, myśleć w kategoriach racjonalnych i konstruktywnych, zawsze na pierwszym miejscu stawiając racje społeczne, a nie - indywidualne. Niektórzy publicyści pisali w ten sposób, jakby poeta ten był prekursorem realsocjalistycznych koncepcji. Apoteozowanie Norwida miało świadczyć również, że komuniści nie walczą $z$ tradycjami polskiej kultury, że wybierają i popierają to, co jest w niej największego (przemilczano oczywiście fakt, że Norwid był poetą religijnym, zupełnie niezrozumiałym, jeśli pomija się jego związek z katolicyzmem), a więc że nie walczą z nimi także wówczas, gdy zakazują wystawiania Dziadów ${ }^{13}$.

Pamiętam, że autor tych słów był obecny jesienią 1985 wśród licznego audytorium konferencji Język Cypriana Norwida, o której tu wspomniałem. Rok wcześniej opublikował w czasopiśmie „Studia Norwidiana” artykuł Gorzkie kalambury. O „Purytanizmie" Cypriana Norwida ${ }^{14}$. Czytałem wtedy ten artykuł jako kontynuacje jego studiów dawniejszych, a zarazem jako głos poprzedzający ważną dla mnie lekturę

9 G. Białk ow sk ki, Otwarcie konferencji. W zb.: Język Cypriana Norwida. Materiały z konferencji zorganizowanej przez Pracownię Stownika Języka Norwida w dniach 4-6 listopada 1985 roku. Red. K. Kopczyński, J. Puzynina. Warszawa 1990, s. 9.

10 A. Za gaj ew s ki, Petit. W: List. Oda do wielości. Nowe wiersze. Kraków 1982, s. 64.

11 S. B a r a ń z z k, Norwid - obecność nieobecnego. W: Tablica z Macondo. Osiemnaście prób wyttumaczenia, po co i dlaczego się pisze. Londyn 1990, s. 105.

12 Ibidem, s. 101.

13 M. Głowiński, Dzieje romantyzmu w PRL. (Najkrótszy kurs). W: Realia, dyskursy, portrety. Studia i szkice. Kraków 2011, s. 73.

14 M. Głowiński, Gorzkie kalambury. O „Purytanizmie” Cypriana Norwida. „Studia Norwidiana” t. 2 (1984). 
wiersza Norwida, zaprezentowana na owej warszawskiej konferencji ${ }^{15}$. W ujęciu Głowińskiego Purytanizm określa swój świat komunikowanych sensów w zwrocie do drugiej osoby, dlatego badacz przede wszystkim analizuje sytuację dialogowa, dobitnie zarysowaną w tekście utworu. I podkreśla swoista „niegotowość” wywodu kształtowanego przez podmiot mówiący, który stale znajdując się w sytuacji dialogu, relatywizuje treść wypowiadanych prawd. Można by rzec, że zaprezentowana w ten sposób teza dobrze egzemplifikuje prawidłowość poetyki Norwida, scharakteryzowaną we wspomnianym tu już artykule Norwidowska druga osoba. Badacz stwierdzał w nim:

Osobliwości owej Norwidowskiej drugiej osoby można by tak określić: wszelkie rozmyślanie nie przebiega w samotności, wymaga partnera, którego obecność wpływać może na tok medytacji, podpowiadać taki czy inny watek, partnera, który może być oponentem i reprezentować inne niż podmiot stanowisko, a więc tym bardziej oddziaływać na krystalizowanie się jego mniemań. Proces rozmyślań w poezji Norwida, a zwłaszcza w większości utworów z Vade-mecum, jest procesem zsocjologizowanym, nie ogranicza się do świadomości rozmyślającego bohatera, jest skierowany na zewnątrz - właśnie ku drugiej osobie ${ }^{16}$.

W interpretacji wiersza Purytanizm poszerzeniu ulega charakterystyka atrybutów podmiotu mówiącego - Głowiński pokazuje, jak podmiot ów, przedstawiając zjawisko $\mathrm{z}$ wielu stron, staje się podmiotem ironicznym, po części przeczącym sobie. Służy temu seria kalamburów związanych $\mathrm{z}$ etymologią słowa tworzącego tytuł utworu. Ironiczność przejawia się tu w zabawie etymologiami, paradoksalnej grze językowej, co każe szukać dla tego sposobu poezjowania analogii w nurtach awangardowych XX wieku, zwłaszcza w poezji lingwistycznej. Głowiński konkluduje:

Wydaje się, że Norwidowski Purytanizm należy zestawiać nie z utworami klasyków poetyckiej lingwistyki, ale z poetami dużo od nich młodszymi, z reprezentantami tzw. nowej fali, która od końca lat sześćdziesiątych jest jednym z poważniejszych zjawisk w polskim życiu literackim. Poeci ci jakby igraszki słowne zsocjalizowali i ideowo sproblematyzowali, postępowali więc nadal jak wirtuozi, ale tacy, którzy mistrzowską grę językową wyzyskali w literaturze o charakterze społecznym czy obywatelskim. Analogia z Purytanizmem narzuca się tu sama. Właśnie analogia, bo zarówno twierdzenie, że Norwid był patronem (czy prekursorem) Stanisława Barańczaka lub - na odwrót - Barańczak epigonem Norwida, byłoby - tak w pierwszej, jak w drugiej wersji - absurdalne ${ }^{17}$.

Badacz nie tylko ciekawie skomplikował i wzbogacił dyskusję o Norwidowskiej ironii, którą rozpoczął kiedyś Kołaczkowski, ale także odnalazł właściwy kontekst historycznoliteracki czytania poety w smutnych latach stanu wojennego.

Uwagi te, zanotowane przeze mnie na marginesie przywołanej tu interpretacji wiersza Purytanizm, zmierzają do takiej oto konstatacji: że Norwid towarzyszy Głowińskiemu w studiach literackich nieprzerwanie, jest poeta dla niego ważnym, którego fenomen badacz rozpatruje w swych pracach po wielekroć, bądź czyniąc z wybranych zagadnien jego twórczości główny przedmiot analiz i rozważań, bądź znajdując w niej egzemplifikacje swoich rozpoznań teoretycznych i formułowanych tez. To właśnie Norwid umożliwia mu odnajdywanie tych znaków czasu, które za-

Zob. E. N ow i cka, „Purytanizm” wobec konwencji listu poetyckiego. W zb.: Język Cypriana Norwida. 
powiadają zmianę w szerszej panoramie życia społecznego, zawsze w jakiś sposób odzwierciedlanej przez literaturę. Głowiński czyta go jako poetę pod wieloma względami awangardowego, co sam przyznaje, zgadzając się w rozmowie-rzece $z$ wypowiedzią Grzegorza Wołowca, który wskazuje na podobieństwo Norwida i Leśmiana:

Wydaje się, że Norwid i Leśmian to poeci różni, z innych epok, że nie mają ze sobą wiele wspólnego. $Z$ tego, co mówiłeś, wynika, że obaj byli outsiderami w czasach, w których tworzyli. Ich poezja miała charakter, paradoksalnie, archaiczno-nowatorski. To było nowatorstwo w obrębie tego, co mogło się wydawać archaiczne. Ta właściwość ich łączy. Okazuje się, że awangarda może więc i tak wyglądaći ${ }^{18}$.

„Przeszłość to dziś, tylko cokolwiek dalej” - ta Norwidowska formuła stosuje się tu do twórczości poety, tłumaczy jej sporne miejsce w czasie, w historii literatury. Formuła ta nie raz jeden pojawia się w porządkowaniu zjawisk literackich przez Głowińskiego, także w porządkowaniu jego indywidualnych doświadczeń, w wymiarze osobistej biografii człowieka żyjącego na przełomie wieków:

Okragłe daty, owe przełomy w domenie czasu, zmieniają w jakiejś przynajmniej mierze wizję własnego życia, pozwalają inaczej niż dotychczas je mierzyć, a więc wyznaczać te jego sfery, które były „przed” i były lub nadal sa „po”. Nie może o tym nie myśleć starszy człowiek, gdy mu się zdarzyło dożyć tak newralgicznego punktu w kształtowaniu społecznego i indywidualnego czasu, jak przełom wieków. Co za jego sprawą ulega zmianie, co zaś pozostaje niezmienione? To prawda, że wszystko, co przeżyte i doświadczone, staje się Norwidowskim „cokolwiek dalej”, można by powiedzieć, że czas przeszły zdobywa mocniejszą pozycję i ma relatywnie mniej danych, by wchodzić w relacje z czasem teraźniejszym, choć to on także określa jego zakres i formę. I to wyostrzenie cezury jest niewątpliwie czynnikiem zmiany. Ale - paradoksalnie (ktoś powiedziałby: dialektycznie) - to, co niezmienne, jest właśnie pochodna zmiany, owego przesunięcia wskazówek zegara z rzymskiej XX na XXI. Urodzony w połowie lat trzydziestych, pozostanę już na zawsze kimś określonym przez wiek XX i przez to, co się w nim stało, pozostanę - choć to nadmiernie patetyczne czy wręcz kabotyńskie - człowiekiem XX wieku - i to niezależnie od tego, ile lat los pozwoli mi przeżyć w wieku następnym ${ }^{19}$.

\section{Przypowieści i interpretacje}

Problem usytuowania autora Vade-mecum w czasie, niedostosowanie jego poezji do XIX-wiecznych nurtów i prądów literackich jest w badaniach norwidologicznych problemem kluczowym. Także dla Głowińskiego, by tak rzec, „niewspółczesna współczesność" poety stanowiła punkt wyjścia w określeniu wyborów narracyjnych Norwida. W swym najważniejszym artykule jemu poświęconym, o „wierszach-przypowieściach”, zwracał badacz uwagę na pozostawanie jego poezji zarówno poza narracją rozumiana jako mit, jak i narracją sprowadzona do mimesis. Dla twórcy dystansującego się wobec technik opowiadania właściwych romantyzmowi i realizmowi inne możliwości wyboru oferowała tradycja literacka, w której Norwid odnalazł - by posłużyć się określeniem Głowińskiego - archaikę narracyjną takich form, jak alegoria, przypowieść i exemplum. Te rozważania o poetyce wierszy z cyklu Vade-mecum stanowiły zarazem analizę ich sytuacji komunikacyjnej z jasno sformułowaną teza - istotną przyczyną nierozumienia Norwida przez jego współ-

18 Głowiński, Wołowiec, op. cit., s. 300.

19 M. Głow ińs ki, Starszy człowiek na przełomie wieków. W zb.: Na początku wieku. Rozważania o tradycji. Red. Z. Troja nowi czowa, K. Trybuś. Poznań 2002, s. 17. 
czesnych był fakt, że wiek XIX rozstał się z gatunkami alegorycznymi, które poeta wyraźnie preferował.

Rozpoznania Głowińskiego mają do dziś walor zasadniczy i nowatorski, przekonują, że alegorie stanowią centrum poetyckiego świata Norwida. Ponadto tłumaczą tragedię autora Quidama niezrozumianego za życia, odtrąconego przez współczesnych. Szczególna jego predylekcja do alegorii i gatunków alegorycznych jest najważniejszą regułą tworzenia, alternatywą wobec poetyki kreacyjnej romantyków. Odczytywanie, a nie tworzenie znaków, odnajdywanie, a raczej unaocznianie sensu znaków już istniejących w świecie - oto główne zadanie Norwidowskich alegorii.

Autor artykułu Norwida wiersze-przypowieści nawiązywał do pionierskich komentarzy Miriama o formie przypowieści zaledwie paru utworów poety (Wita-Stosa pamięci estetycznych zarysów siedem, Pokój, Dwa męczeństwa), do pracy Ireny Sławińskiej o parabolicznej strukturze jego opowiadań i do niektórych spostrzeżeń Gomulickiego na temat roli przypowieści w twórczości Norwida. Swej analizie alegorycznych struktur poetyckich nadał Głowiński charakter systemowy i w pewnym sensie - systematyczny, co nietypowe w przypadku metod odwołujących się do strukturalistycznego ukierunkowania badawczego. Otrzymaliśmy nie tylko modelową charakterystykę opisywanego zjawiska, ale także wyczerpująca analizę typologiczna parabolicznych form narracyjnych stosowanych przez Norwida w jego liryce - legendy, ballady, dialogu, bajki, rozbudowanego porównania, exemplum. Ważne w tych analizach jest rozróżnienie na kompozycję hipotaktyczną i parataktyczną, wyjaśniającą związek przypowieści z otaczającym ją dyskursem. Poza strukturalnymi „wglądami” w sferę ukrytych zasad budowy przywoływanych w artykule wierszy-przypowieści znajdujemy w nim spory zbiór mikrointerpretacji tych właśnie utworów. I to głównie czyni ów zasadniczy tekst o poetyce Norwida tak bardzo do dzisiaj atrakcyjnym. Sens-świata, Sieroctwo, Dwa męczeństwa, Znów legenda, Wielkość, Naturalizm. (Spółczesny ekstrem), „Ołówkiem” na ksiażce o Tunce, Teofilowi, Liryka i druk, Mistycyzm, Przeszłość, laur dojrzały, Królestwo, Niebo i ziemia, Krzyż i dziecko, Sfinks, Po balu, Marionetki - wszystkie te przywołane wiersze Norwida odsłaniają, choćby we fragmencie, często wycinkowo, jakiś rodzaj semantycznego konkretu związanego z ogólnym przesłaniem danego utworu, który w ujęciu interpretacyjnym Głowińskiego zawsze ujawnia indywidualne cechy swojego przekazu. Bodaj czy nie najważniejsza to cecha naukowego pisarstwa tego badacza, tak wyraźna w książkach o poezji Tuwima i Leśmiana. Widoczna także w omawianych tu studiach o Norwidzie, przede wszystkim jako stale zaznaczane świadectwo lektury i manifestacyjna wręcz koncentracja uwagi na akcie czytania tekstu poetyckiego będacego przedmiotem analizy.

Nie inaczej jest w artykule Ciemne alegorie Norwida $^{20}$ z 1983 roku, pomyślanym jako dopełnienie wcześniejszych ustaleń o wierszach-przypowieściach. I tym razem dominuje perspektywa poetyki odbioru - autor artykułu wskazuje na czynniki powodujące „ciemność Norwida”, pojmowaną jako sytuacja komunikacyjna między poetą a jego czytelnikami. Po pierwsze: wieloperspektywiczność w oglądzie rzeczywistości przez podmiot wiersza, powodująca polifoniczność tekstu poetyckiego, po

20 Pierwodruk w zb.: Cyprian Norwid. W setna rocznice śmierci poety. Materiały z sesji poświęconej życiu i twórczości C. Norwida (27-29 października 1983). Red. nauk. S. B u rkot. Kraków 1991. 
drugie: ostry montaż elementów współtworzących ten tekst, po trzecie: traktowanie czasu i przestrzeni w świecie przedstawionym wiersza w sposób niezgodny ze znanymi konwencjami, po czwarte: politematyczność związana $z$ dygresyjnością narracji, prowadzaca do otwartej kompozycji utworu lirycznego. Ta analiza zasad budowy alegorycznych struktur w poezji Norwida ma jednak dominante interpretacyjna - systemowa analiza przechodzi w lekture wiersza Rozebrana. Przeprowadzona interpretacja tego utworu pełni funkcję exemplum dla ustaleń o charakterze ogólnym i mogłaby wszakże stanowić samodzielną wypowiedź jako fragment interpretacyjny o dużym stopniu konkretności.

Tę potrzebę uprzywilejowania interpretacji w pracach o charakterze teoretycznym wytłumaczy Głowiński po latach w szkicu Norwid i Jakobson. (O granicach lingwistycznej analizy poezji) ${ }^{21}$. Przywołując klasyczne pozycje Jakobsona poświęcone wierszom Przeszłość i Czułość, stwierdzi:

I tu od razu ujawnia się czynnik, który ogranicza znaczenie obydwu rozpraw o autorze Vade-mecum dla tych wszystkich, których interesuje jego twórczość: w Jakobsonowskich rozważaniach o Norwidzie ważny w istocie nie jest Norwid, badacza zajmują ogólne mechanizmy, a one ujawniać się mogą w jakichkolwiek tekstach, jeśli spełnią one formalne warunki, uważane za wyróżniki poezji niezależnie od tego, jakie dane teksty wierszowane mają konkretne właściwości i czy reprezentują jakąś wartość. Można powiedzieć, że konflikt między założeniami prac Jakobsona tego typu a oczekiwaniami tych, którzy pragna znaleźć w nich omówienia czegoś, co byłoby charakterystyczne dla utworów wielkiego poety, jest konfliktem między analizą egzemplaryczną a interpretacją, konflikt zarysowujący się między ujawnianiem cech ogólnych a dążeniem do wyjaśnienia indywidualnych właściwości konkretnego przekazu ${ }^{22}$.

Autor tej wypowiedzi zwraca też uwagę na to, że specyfika uprawianej przez Jakobsona lingwistycznej analizy poezji prowadzi do pomijania współczynnika aksjologicznego, który jest niezbywalnym komponentem lektury. Wydaje się, że alternatywa dla tej odmiany metodologii strukturalistycznej jest właśnie nurt refleksji strukturalistycznej, którą uprawia Głowiński w artykułach o Norwidzie i o innych twórcach.

Jeśli napisałem o nowatorstwie tych tekstów, zwłaszcza dotyczących alegorycznych struktur wierszy zgromadzonych w Vade-mecum, to miałem na myśli nie tylko ich doniosłość w chwili publikacji, ale także wciąż dziś aktualna zdolność inspirowania nowych odczytań Norwida. Warto podkreślić, że rozważania o alegoryczności jego poezji współtworzyły szerszy proces przewartościowania stosunku do alegorii zapoczątkowany w estetyce przez Gadamera jeszcze w końcu lat pięćdziesiątych XX wieku, mający swoje długie trwanie w europejskiej, w tym także polskiej refleksji. I choć Głowiński nie nawiązuje wprost do autora Prawdy i meto$d y$, to kontekst teoretyczny jego rozważań stanowia prace zachodnich badaczy literatury, zainteresowanych renesansem alegorii, który wyzwoliła ogłoszona przez Gadamera potrzeba jej „rehabilitacji” ${ }^{23}$. Niektóre spośród tych artykułów ukazały się w dziale przekładów „Pamiętnika Literackiego” w 1975 roku, a po latach zostawnętrzny Telimeny i inne szkice. Kraków 2007.

22 Ibidem, s. 150-151.

23 H. G. Gadamer, Symbol i alegoria. Przeł. M. Łukasiewicz. W zb.: Symbole i symbolika. Wybór, wstęp, oprac. M. Głowińs ki. Warszawa 1990. 
ły opublikowane w tomie Alegoria, w serii „Archiwum Przekładów "Pamiętnika Literackiego"” pod redakcją Michała Głowińskiego ${ }^{24}$, już z uwzględnieniem studium Paula de Mana Retoryka czasowości, przełożonego na język polski dużo później niż pozostałe teksty. Jeśli pamietać też o tym, co do renesansu alegorii wnosi współczesna recepcja pism Waltera Benjamina, okaże się, że możliwości ciągłego redefiniowania pojęcia alegorii w odniesieniu do poezji Norwida wykraczają poza ustalenia Głowińskiego, prowadząc w stronę filozofii i antropologii literatury. A jednocześnie warto rezultaty tych ustaleń brać pod uwagę, bo stwarzaja jasna podstawę przyswojenia tych redefinicji w oparciu o kategorie właściwe poetyce historycznej. Dobrze się stało, że Głowiński czytał wiersze Norwida dla „poezji”, przed czym przestrzegała Dorothy Sayers, która uprzywilejowała znaczenie w alegorycznym przekazie, a nie jego warstwę dosłowną, umożliwiającą ujawnienie wartości poetyckiej. Nie ze wszystkimi badaczami alegorii, których Sayers przytacza w swym artykule, było Głowińskiemu po drodze.

Uznanie alegorii za centrum poetyckiego świata Norwida pozwala podejmować najtrudniejszą kwestię norwidologii, która dotyczy ciąłłego sporu o miejsce poety w historii literatury. Nawiązujący do Głowińskiego Arent van Nieukerken pokazuje, jaki dystans dzieli twórcę Vade-mecum od francuskiego symbolizmu. Norwid przeciwstawiał mu archaiczne sposoby mówienia, prymat tematu i tezę o historyczności ludzkiego bytowania ${ }^{25}$. Wybór alegorii umożliwiał Norwidowi krytyczną dyskusję z jego współczesnością, stał się podstawą tego, co holenderski slawista nazwał ironicznym konceptyzmem, który dał początek nowoczesnej poezji metafizycznej.

Pozostając w kręgu Norwidowskich alegorii, zwłaszcza tych wiodących życie toposu, można opisywać całe obszary w jego twórczości - topikę ogrodu, topos księgi i muzy, metafory teatralne, żeglarskie i inne. Szybko jednak okaże się, że toposy te nie wracają $\mathrm{w}$ poezji autora Vade-mecum $\mathrm{w}$ wersjach znanych literaturze przedromantycznej. Mamy do czynienia $z$ materią topiczną, która występuje tu $\mathrm{w}$ wielkim pomieszaniu, poza dawnym porządkiem elokucyjnym, podlegając indywidualnym regułom tworzenia ${ }^{26}$.

\section{Jaki Norwid?}

Wieloznaczny - przede wszystkim tę cechę poetyki Norwida wydobywają ślady lektur jego wierszy zapisane w przywołanych tu artykułach Głowińskiego. Wskazać można różne przyczyny tej wieloznaczności. Po pierwsze - struktura czasu w utworach, czasu wykraczającego poza „tu i teraz” przedstawianych zdarzeń. Czasu, który przybiera różne postaci - historii, wieczności i codzienności. Jest czasem odpominanym, czasem teraźniejszości odnalezionym w przeszłości, niejednokrotnie zniszczonym, danym tylko we fragmencie. Alegoria Norwida nie zatrzymuje czasu,

Alegoria. Red. J. A bram ow s ka. Gdańsk 2003. „Archiwum Przekładów "Pamiętnika Literackiego". Red. M. Głowiński.

25 A. van Nieukerken, O „niewczesności” Norwida, dwóch modernizmach i Miłoszu. „Teksty Drugie” 1995, nr 6. Zob. też tego autora: Ironiczny konceptyzm. Nowoczesna polska poezja metafizyczna $w$ kontekście anglosaskiego modernizmu. Kraków 1998, s. 102-106. 
co wydaje się cechą symbolu, zwłaszcza w przypadku jego funkcji mityzacyjnej ${ }^{27}$. Głowiński pokazuje, jak bardzo struktura czasu w wierszach poety zależy od jego stosunku do tradycji literackiej, do której odsyła alegoria, będąca zawsze efektem dokonanego wyboru, często niełączącego się systemowo $z$ innymi wyborami $z$ literackiej przeszłości. $Z$ cała pewnością te wybory $\mathrm{z}$ tradycji w przypadku Norwida motywowane sa świadomością kryzysowa, co ujawnia i zaświadcza jego poezja, którą Głowiński nazywa - jak dobrze pamiętamy - „poezją form przesuniętych”.

Bliski tym rozpoznaniom jest $\mathrm{z}$ pewnością Rolf Fieguth, który w swym studium o Vade-mecum jako „poezji w fazie krytycznej” pisał o funkcji estetycznej świadomie przez Norwida kształtowanych zakłócen ${ }^{28}$. Obaj ci badacze akcentując znaczenie religijnego charakteru jego twórczości, pokazuja, jak daleko twórczość ta plasuje się od tradycjonalizmu religijnego. $\mathrm{W}$ ich lekturze wiersze poety staja się pytaniem o sens krystalizujący się w odniesieniu do świata wartości chrześcijańskich, bez zamykania przesłania tych utworów w prawdach wiary. Zarówno Głowiński, jak i Fieguth czynią w ten sposób z dziedzictwa Norwida dzieło otwarte, wolne od światopoglądowych zawłaszczeń i jakiejkolwiek ideologizacji.

Pośród wielu odnotowanych przez Głowińskiego środków poetyckich, które sprawiaja, że przekaz Norwida staje się wieloznaczny, warto wymienić tu szczególną rolę konwencji właściwej poematom dygresyjnym. Dygresyjność nie tylko jest, zdaniem badacza, cechą większych utworów narracyjnych, jak poematy Assunta czy Quidam, ale uwidacznia się także w utworach drobnych, wchodzących w skład Vade-mecum, co doskonale Głowiński wykazał, analizując przywołany tu już wiersz Purytanizm. Obserwacja ta demonstruje też swobodny związek Norwida z estetyką romantyzmu i jej formalnymi wynalazkami w sferze tworzenia literatury. Poeta pozostaje w silnej relacji z romantyzmem tam zwłaszcza, gdzie przekształcenie form estetycznych w epoce Byrona zapraszało swą śmiałością do dalszych eksperymentów. Najlepszym tego przykładem jest podejście Norwida do epopei, rozumianej jako kategoria estetyczna, niewiążąca już utworu uznawanego za epos z katalogiem ściśle określonych cech formalnych, co Głowiński dowodnie wykazał, wyjaśniając przy okazji stosunek poety do współczesnej mu powieści.

Autor „nienapisanej książki” o Norwidzie, której fragmenty tu przytaczam i analizuję, konsekwentnie czyta jego poezję poprzez wykorzystanie topiki ironicznej. Na znaczenie formuły budowania sensów zaprzeczonych zwracało uwagę wielu badaczy. $Z$ pewnościa źródła estetyczne ironii poety są romantyczne, tyle że ironia romantyczna miała antyczne antecedencje $i$ korzystała $z$ szerokiego dziedzictwa przedromantycznej literatury (np. ariostyzm Słowackiego). W epoce romantyzmu nie było też jednego uzasadnienia teoretycznego dla ironicznego pisarstwa - by przywołać propozycje tak odmienne, jak te, których dostarczyli niezależnie od siebie Schlegel i Kierkegaard.

Głowiński analizując mechanizmy ironicznych zaprzeczeń w poezji Norwida, zwrócił uwagę na szczególną funkcję słowa oraz aktywną rolę języka w poznawaniu

27 Zob. L. Koła kow s ki, Mircea Eliade - religia jako paraliż czasu. W: Pochwała niekonsekwencji. Pisma rozproszone z lat 1955-1968. Przedm., wybór, oprac. Z. M e n tzel. T. 3. Warszawa 1989.

28 R. Fi egut h, Poezja $w$ fazie krytycznej. Cykl wierszy Cypriana Norwida „Vade-mecum”. „Studia Norwidiana" t. $3 / 4(1985 / 86)$. 
rzeczywistości za pośrednictwem wiersza korzystającego z aforyzmów i kalamburów. Przesunął tym samym refleksję o źródłach wieloznaczności tej twórczości w stronę XX-wiecznej poezji lingwistycznej. Pamiętając o związkach słowa Norwida z greckim Logos, wskazywał jednocześnie na awangardowy charakter pisarstwa autora Vade-mecum. I najbardziej nośną formułę dla niego odnalazł właśnie w wieku XX, przytaczając słowa, które Witold Gombrowicz, wypowiedział o sobie: „konserwatywny awangardzista i awangardowy konserwatysta"29.

Mimo że od czasów, w których powstawały studia Głowińskiego o Norwidzie, minęły lata, trudno nie zgodzić się $\mathbf{z}$ następującą konstatacją:

Sztuka czytania tzw. ciemnej poezji (a za taką przecież twórczość Norwida do dzisiaj uchodzi), to wgłębianie się w tę ciemność, usiłowanie zrozumienia jej reguł i zasad, jej specyficznego porządku. Sztuka ta polega więc na tym, by odnaleźć odpowiednie dla wiersza sposoby lektury ${ }^{30}$.

\author{
Abstract \\ KRZYSZTOF TRYBUŚ Adam Mickiewicz University, Poznań \\ ORCID: 0000-0002-4285-4595
}

\title{
NORWID IN MICHA£ GLOWIŃSKI'S RESEARCH-SOME REMARKS
}

The article is devoted to Michał Głowiński's papers in Norwid studies. The author attempts to situate Głowiński's papers in the broad context of his examinations of Polish poetry, thus the investigations into Tuwim and Leśmian, as well as such theoretical sketches in which Norwid's poetry serves as an instructive exemplum to support the observations, are recalled. The author's attention is primarily focused on Głowiński's revealing identifications referring to the structure of parables in the poems from the volume Vade-mecum. Trybus poses questions about the significance of the aforementioned identifications to the development of Norwid studies and sets them into a historical perspective, seeks relationships between Głowiński's research in Norwid's allegory and Gadamer's "rehabilitation of allegory," and finally reconstructs the peculiar style of reading of so-called dark poetry based mostly on the art of interpretation.

D. de Roux, Rozmowy z Gombrowiczem. Paryż 1969, s. 128. Cyt. za: Głow iń s ki. Wokót „Powieści" Norwida, s. 339.

30 Głowińs ki, Odpowiednie dać rzeczy słowo, s. 351. 